\title{
The Correlation between Islamic Spirituality and Distress in Type 2 Diabetes Mellitus Patients
}

Korelasi antara Spiritualitas Islam dan Distres pada Pasien Diabetes Melitus Tipe 2

\author{
Adang Muhammad Gugun ${ }^{1 *}$, Yusuf Alam Romadhon ${ }^{2}$, Gina Nidaulfalah ${ }^{3}$, Suci Aprilia ${ }^{4}$ \\ ${ }^{1}$ Clinical Pathology Department, Faculty of Medicine and Health Science, Universitas Muhammadiyah Yogyakarta \\ 2 Family Medicine Department, Faculty of Medicine, Universitas Muhammadiyah Surakarta \\ ${ }^{3}$ Faculty of Medicine and Health Science, Universitas Muhammadiyah Yogyakarta \\ ${ }^{4}$ Faculty of Medicine, Public Health and Nursing, Universitas Gadjah Mada
}

DATA OF ARTICLE:

Received: 05 Jan 2021

Reviewed: 29 June 2021

Revised: 05 July 2021

Accepted: 08 July 2021

*CORRESPONDENCE:

adang_patklin@yahoo.com

DOI:

10.18196/mmjkk.v21i2.10848

TYPE OF ARTICLE:

Research

\begin{abstract}
More than half of people with Diabetes Mellitus experience distress. Spirituality-religiosity strengthens mental health status through coping mechanism for handling distress in type $2 \mathrm{DM}$ patients. The majority of the population in Indonesia is Muslim; therefore, this study aims to determine the correlation between Islamic spirituality and distress in type $2 \mathrm{DM}$ patients. This research is an analytic observational study with a cross-sectional approach conducted at PKU Muhammadiyah Gamping Hospital. Subjects were type 2 DM patients, both outpatient and inpatient, diagnosed at least more than six months. Interviews about spirituality used the Holistic Health Care (HHC) questionnaire, while distress used the Diabetes Distress Screening Scale (DDSS) questionnaire. The data analysis was carried out using the Spearman test and Somers'd test. Forthy six subjects were obtained with an age range between 45 to 75 years old. Based on the data analysis, it showed that there was a positive correlation ( $\mathrm{p} 0.020 ; \mathrm{r}-0.343$ ) between Psychospiritual and DM Distress scores. Furthermore, there was a moderate correlation between Islamic spirituality and distress in type 2 DM patients.
\end{abstract}

Keywords: Diabetes Mellitus; distress; DM type 2; Islamic spirituality

Abstrak: Lebih dari separuh pasien Diabetes Melitus mengalami distres. Spiritualitasreligiusitas mengokohkan status kesehatan mental melalui mekanisme koping penanganan distres pada pasien DM tipe 2. Mayoritas penduduk di Indonesia beragama Islam, oleh karenanya tujuan penelitian ini untuk mengetahui hubungan spiritualitas Islam dan distres pada pasien DM tipe 2. Penelitian ini merupakan penelitian observasional analitik dengan pendekatan potong lintang yang dilakukan di RS PKU Muhammadiyah Gamping. Subyek merupakan pasien DM tipe 2 baik rawat jalan maupun rawat inap yang didiagnosis minimal lebih dari 6 bulan. Wawancara mengenai spiritualitas menggunakan kuesioner Holistic Health Care (HHC) dan distres menggunakan kuesioner The Diabetes Distress Screening Scale (DDSS). Analisis menggunakan uji spearman dan uji somers'd. Didapatkan 46 subyek dengan rentang umur antara 45 sampai dengan 75. Hasil analisis uji Spearman antara skor Psychospiritual dan skor Distres DM, didapatkan nilai r -0,343 dengan p 0,020. Terdapat korelasi sedang antara spiritualitas Islam dan distres pada pasien DM tipe2.

Kata Kunci: distres; Diabetes Melitus; DM tipe 2; spiritualitas Islam 


\section{INTRODUCTION}

The prevalence of people with Diabetes Mellitus (DM) worldwide is very high and tends to increase every year. According to the results of the Indonesian Ministry of Health, it was found that the prevalence of diabetes mellitus increased by $2.6 \%$ compared to 2013 and reached 14 million people. ${ }^{1}$ Risk factors associated with type $2 \mathrm{dm}$ include anxiety and a history of distress. ${ }^{2}$ The state of distress continues when a person is diagnosed with DM. More than a third of diabetes patients suffer from distress and depression. More than half of DM sufferers experience anxiety. ${ }^{3}$

Patients with DM have an anxiety level 20\% higher than people without DM. Anxiety disorders have a close relationship with hyperglycemia in people with diabetes. ${ }^{4}$ High blood sugar levels and the risk of complications make every DM sufferer experience anxiety. ${ }^{5}$ The management strategy for type 2 diabetes that has been recommended is basically only using a biological approach. On the other hand, the holistic approach is a broader and fundamental approach, covering bio-psychospiritual aspects. ${ }^{6}$

Spirituality / religiosity can strengthen mental health status through coping mechanisms in dealing with stress. ${ }^{7}$ Increasing spirituality is a determinant of the successful management of type 2 diabetes control. ${ }^{8}$ The basic effort to increase spirituality is to increase awareness of spirituality. Increasing awareness of spirituality also includes supporting religious ritual activities. ${ }^{9}$ According to Soudagar and Rambod, there is a relationship between spirituality and levels of anxiety and depression. ${ }^{3}$

Indonesia is a country that has a majority Muslim population. The holistic approach to managing type 2 diabetes mellitus through Islamic spirituality is very relevant. According to Islamic spirituality is the embodiment and expression of the awareness of Allah SWT, knowledge, worship practices and various values established in Islam. Chen et al. stated that the subject of Islamic spirituality is love and closeness to God related to dedication to individual limitations..$^{10}$ This closeness is accompanied by love as the essence of subjective experience which will motivate further devotion in a cycle to deepen the belief over time. ${ }^{10} \mathrm{Holistic}$ health management is a healing effort that takes into account biological, psychological, social and spiritual aspects carried out by health workers who are used in an integrated and comprehensive service management system. Broadly speaking, the goal of holistic health management is to obtain information and descriptions related to aspects of psychospiritual, etiological, interrelationships, therapy and patient-focused care so that needs are met and get a healthier life. ${ }^{11}$ A study of the correlation between Islamic spirituality and distress in type 2 DM patients needs to be done to further strengthen the basis for its application. Many studies related to spirituality in DM have been carried out, especially regarding the role of spiritual needs in the management of DM patients. ${ }^{12,13}$ While research on the correlation between Islamic spirituality and distress in type 2 DM patients has never been done. The aims of this research to determine the correlation between Islamic spirituality and distress in type 2 DM patients.

\section{MATERIALS AND METHOD}

This research is an analytic observational study with a cross sectional approach. This study had received approval from the Health Research Ethics Commitee of the Faculty of Medicine and Health Science, Universitas Muhammadiyah Yogyakarta with the number 167/EC-KEPK FKIK UMY/VI/2020.

The study was conducted in three months from September to November 2020. The research subjects were type 2 diabetes mellitus patients who were treated at PKU Muhammadiyah Gamping Hospital. Subjects were obtained through concecutive sampling based on inclusion and exclusion criteria and gave consent through informed concent. Subjects were type 2 DM patients both outpatient and inpatient diagnosed at least more than 6 months in 2020. The inclusion criteria of this study were type 2 DM patients with composmentis awareness, type 2 DM patients who were inpatient and outpatient at PKU Muhammadiyah Hospital, Gamping, Yogyakarta and were cooperative and participated in the study. While the exclusion criteria were type 1 DM patients, gestational DM, specific type DM related to other causes, type 2 DM patients who were not hospitalized and/or outpatient at PKU Muhammadiyah Hospital, Gamping, Yogyakarta and respondents who were not involved in the study.

Subjects were interviewed about spirituality using the Holistic Health Care (HHC) questionnaire and distress using the The Diabetes Distress Screening Scale (DDSS) questionnaire. The DDS questionnaire has a validity of $0.534-0.607$ and a reliability of $0.87 .{ }^{14}$ The data collected is primary data. Furthermore, the data were analyzed using SPSS 15 program. Univariate test is used to determine the description of respondents. bivariate analysis using the Spearman test to determine the relationship between Islamic spirituality scores and distress scores and the Sommers'd test to determine the relationship between Islamic spirituality and distress with categorical data. 


\section{mutiara medika}

RESULT

The study was followed by 46 participants with the characteristics as presented in Table 1. The research subjects consisted of 28 female and 18 male with an age of 45 - 75 years in range.

Table 1. Subject Characteristic

\begin{tabular}{|c|c|c|}
\hline & Total & $\%$ \\
\hline \multicolumn{3}{|l|}{ Gender } \\
\hline Male & 18 & 39.1 \\
\hline Female & 28 & 60.9 \\
\hline \multicolumn{3}{|l|}{ Age } \\
\hline $45-50$ years old & 6 & 13.0 \\
\hline $51-55$ years old & 8 & 17.4 \\
\hline $56-60$ years old & 9 & 19.6 \\
\hline 61-66 years old & 14 & 30.4 \\
\hline $66-70$ years old & 6 & 13.0 \\
\hline $71-75$ years old & 3 & 6.5 \\
\hline \multicolumn{3}{|l|}{ Acceptance } \\
\hline Acceptance Positive & 37 & 80.4 \\
\hline Acceptance Negative & 9 & 19.6 \\
\hline \multicolumn{3}{|l|}{ Obbidient } \\
\hline Obbidient Positive & 33 & 71.7 \\
\hline Obbidient Negative & 13 & 28.3 \\
\hline \multicolumn{3}{|l|}{ Psychospiritual Status } \\
\hline Sorrow & 6 & 13.0 \\
\hline Guide & 8 & 17.4 \\
\hline Revive & 2 & 4.3 \\
\hline Nirvana & 30 & 65.2 \\
\hline \multicolumn{3}{|l|}{ Distress DM } \\
\hline Not depressed/mild depression & 30 & 65.2 \\
\hline Moderate depression & 13 & 28.3 \\
\hline Severe depression & 3 & 6.5 \\
\hline Total & 46 & 100 \\
\hline
\end{tabular}

Table 1 shows that the respondents were more male than female. Most of them are aged 61-66 years as many as 14 respondents (30\%). Most of the respondents had received acceptance of the DM disease (80.4\%), while the rest had not received it (19.6\%). Thirty three people (71.7\%) performed obedience in carrying out the prayers, whereas 13 people (28.3\%) did not. The Psychospiritual Status Category obtained consecutive results Nirvana (full of meaning) 30 people (65.2\%), Guide (guidance) 8 people (17.4\%), Sorrow (Miserable) 6 people (13\%) and Revive (Awakening) 2 people (4.3\%). The most distress category experienced by respondents was no depression / mild depression (65.2\%), followed by moderate depression (28.3\%) and the last severe depression (6.5\%).

Table 2 shows some of the items on the reception desk. Most respondents thought that their current state was sick (45.7\%). The most respondents (43.5\%) expressed the perception of pain as a trial, warning and grace. The most respondent item response to respondents is that most of them receive (60.9\%). The last item regarding the hope of the respondent is optimistic about Allah SWT (45.7\%). Table 2 also shows several items on the obedience in worship. Half of the respondents reported always praying when they were healthy or sick (50\%). Effort / prayer and support were the most expressed by respondents in helping healing (63\%). God / religion is in a sick condition, the most respondents expressed the meaning of being full of love (71.7\%). 
Table 2. Holistic Health Care Score of Subjects

\begin{tabular}{|c|c|c|}
\hline & Total & $\%$ \\
\hline \multicolumn{3}{|l|}{ Holistic Health Care (Acceptance) } \\
\hline \multicolumn{3}{|l|}{ What is currently thinking } \\
\hline Sick & 21 & 45.7 \\
\hline Problems in the family & 3 & 6.5 \\
\hline Cost & 8 & 17.4 \\
\hline Others & 14 & 30.4 \\
\hline \multicolumn{3}{|l|}{ Perseption of the disease } \\
\hline Sick as normal & 11 & 23.9 \\
\hline Sick as the injustice of Allah SWT & 2 & 4.3 \\
\hline Sick as fate & 13 & 28.3 \\
\hline Sick as a trial, a warning and a grace & 20 & 43.5 \\
\hline \multicolumn{3}{|l|}{ The Feeling illness } \\
\hline Not accept & 2 & 4.3 \\
\hline Angry & 3 & 6.5 \\
\hline Sad & 13 & 28.3 \\
\hline Acceptance & 28 & 60.9 \\
\hline \multicolumn{3}{|l|}{ Views on the future } \\
\hline Pessimist & 2 & 4.3 \\
\hline Silent & 3 & 6.5 \\
\hline Doubt & 20 & 43.5 \\
\hline Optimistic because of Allah SWT & 21 & 45.7 \\
\hline \multicolumn{3}{|l|}{ Holistic Health Care (Obbidient) } \\
\hline \multicolumn{3}{|l|}{ Pray as long as healthy and sick } \\
\hline Never pray & 2 & 4.3 \\
\hline Sometimes & 13 & 28.3 \\
\hline When healthy pray, when sick do not pray & 8 & 17.4 \\
\hline Always pray & 23 & 50.0 \\
\hline \multicolumn{3}{|l|}{ Things that can help healing } \\
\hline Do not know & 1 & 2.2 \\
\hline Family motivation & 11 & 23.9 \\
\hline Doctor & 5 & 10.9 \\
\hline Efforts, prayers and support from all parties & 29 & 63.0 \\
\hline \multicolumn{3}{|l|}{ The meaning of Allah SWT } \\
\hline Unfair & 4 & 8.7 \\
\hline Tie and organize & 9 & 19.6 \\
\hline Protect lovingly & 33 & 71.7 \\
\hline Total & 46 & 100 \\
\hline
\end{tabular}

Table 3. Results of the Analysis of the Difference between Psychospiritual Status with Age and Gender

\begin{tabular}{|c|c|c|c|c|c|c|c|c|c|c|c|c|}
\hline & & \multicolumn{8}{|c|}{ Psychospiritual Status } & \multicolumn{2}{|c|}{ Total } & \multirow{3}{*}{$\mathrm{p}$} \\
\hline & & \multicolumn{2}{|c|}{ Sorrow } & \multicolumn{2}{|c|}{ Guide } & \multicolumn{2}{|c|}{ Revive } & \multicolumn{2}{|c|}{ Nirvana } & \multirow{2}{*}{$\mathrm{n}$} & \multirow{2}{*}{$\%$} & \\
\hline & & $\mathrm{n}$ & $\%$ & $\mathrm{n}$ & $\%$ & $\mathrm{n}$ & $\%$ & $\mathrm{n}$ & $\%$ & & & \\
\hline \multirow{6}{*}{ Age } & $45-50$ years old & 1 & 2.2 & 3 & 6.5 & 0 & 0 & 2 & 4.3 & 6 & 13 & \multirow{6}{*}{$0.544^{*}$} \\
\hline & $51-55$ years old & 1 & 2.2 & 1 & 2.2 & 1 & 2.2 & 5 & 10.9 & 8 & 17.4 & \\
\hline & $56-60$ years old & 2 & 4.3 & 0 & 0 & 1 & 2.2 & 6 & 13 & 9 & 19.6 & \\
\hline & $61-66$ years old & 2 & 4.3 & 2 & 4.3 & 0 & 0 & 10 & 21.7 & 14 & 30.4 & \\
\hline & $66-70$ years old & 0 & 0 & 2 & 4.3 & 0 & 0 & 4 & 8.7 & 6 & 13 & \\
\hline & $71-75$ years old & 0 & 0 & 0 & 0 & 0 & 0 & 3 & 6.5 & 3 & 6.5 & \\
\hline \multirow[t]{2}{*}{ Gender } & Male & 3 & 6.5 & 2 & 4.3 & 2 & 4.3 & 11 & 23.9 & 18 & 39.1 & \multirow[t]{3}{*}{$0.709^{*}$} \\
\hline & Female & 3 & 6.5 & 6 & 13 & 0 & 0 & 19 & 41.3 & 28 & 60.9 & \\
\hline Total & & 6 & 13 & 8 & 17.4 & 2 & 4.3 & 30 & 65.2 & 46 & 100 & \\
\hline
\end{tabular}




\section{mutiara medika}

Table 4. Results of the Analysis of the Difference between Distress with Age and Gender

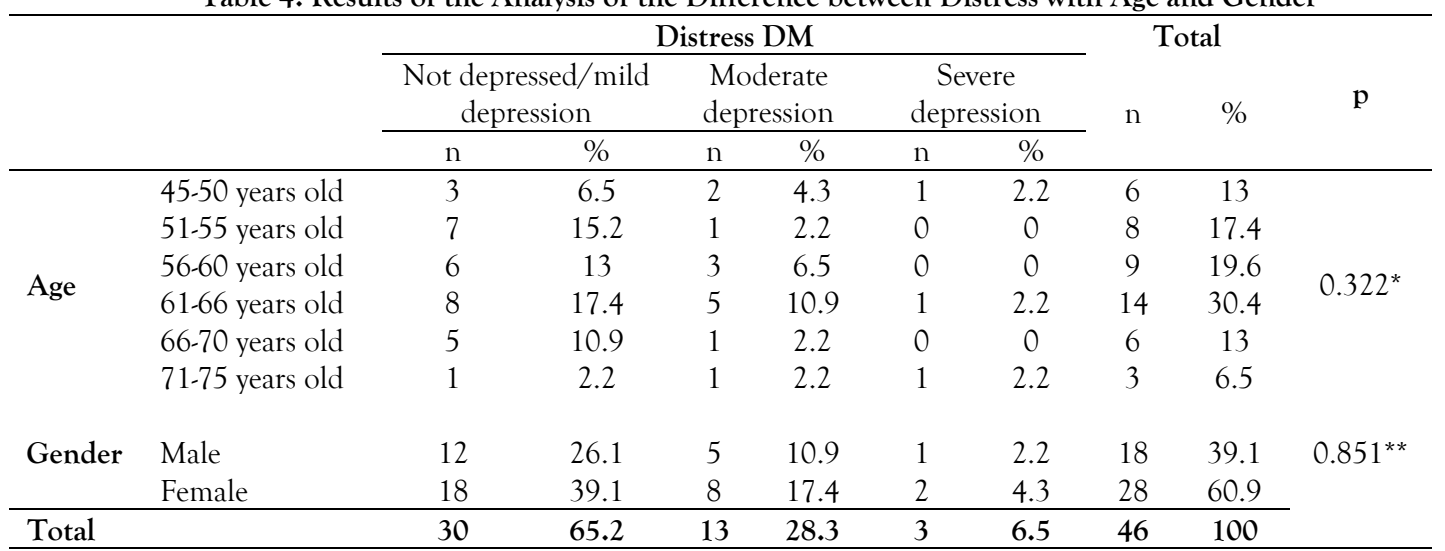

${ }^{*}$ Kruskall Wallis; **MannWhitney

Table 5. Correlation between Psychospiritual and Distress

\begin{tabular}{lccccc}
\hline & Median & Minimum & Maximum & $\mathbf{r}$ & $\mathrm{p}$ \\
\hline Psychospiritual Score & 21 & 12 & 24 & -0.343 & 0.020 \\
Distress Score & 1.74 & 1 & 4.35 & \\
\hline
\end{tabular}

Table 6. Correlation between Psychospiritual Status and Distress

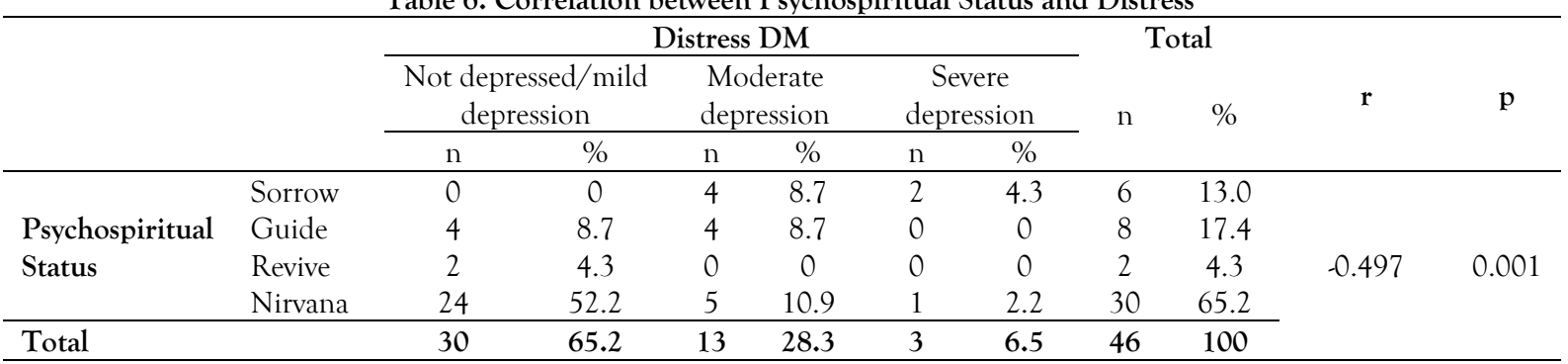

Table 3 contains results of the analysis of the difference between psychospiritual status with age and gender. The results of the test for different psychospiritual status between the age groups obtained p 0.544 ( $p>0.05)$, which means that there is no significant difference in psychospiritual status between age groups. The results of the psychospiritual status difference test between the sex groups obtained $p 0.709$ ( $p>0.05)$, which means that there is no significant difference in psychospiritual status between the sex groups.

Table 4 contains the results of the analysis of the difference between distress with age and gender. The results of the distress difference test between age groups obtained $p 0.322$ ( $p>0.05)$, which means that there is no significant difference in distress between age groups. The results of the distress difference test between the gender obtained p 0.851 ( $p>0.05$ ), which means that there is no significant difference in distress between the gender groups.

Table 5 contains the correlation between psychospiritual score and distress score. The correlation test between psychospiritual scores and distress scores used the Spearman test because the data were not normally distributed. Correlation test obtained $\mathrm{p} 0.020(\mathrm{p}<0.05)$ and $\mathrm{r}-0,343$, it can be concluded that there is a correlation between the two. There is a weak correlation strength which is inversely proportional, the higher the Psychospiritual score, the lower the distress score.

Table 6 contains the correlation between psychospiritual status and distress. Psychospiritual and DM distress were also used as categorical data and analyzed the correlation test using the Sommers' $d$ test. The analysis results showed the value of $\mathrm{p} 0.001(\mathrm{p}<0.05)$ and the value of $r-0.497$. These results can be concluded that there is a correlation between psychospiritual and distress with the strength of a moderate correlation that is inversely proportional, meaning that the higher the subject's psychospiritual, the lower they DM distress.

\section{DISCUSSION}

The proportion of the number of subjects in this study was more in women than men in line with the prevalence of DM patients more in women. ${ }^{15}$ According to Irawan an increase in risk for women is related to an increase in the Body Mass Index. ${ }^{16}$ In the study, this age range group was more in the 61-66 age group as 
much as $30.4 \%$. The incidence of insulin resistance and decreased insulin products increases with age. ${ }^{17}$ Increased risk of diabetes with increased age, especially at the age of $45-64$ years. ${ }^{18}$ The dominance of the 61-66 years age group in this study is related to the volunteerism of the subjects participating in this study.

Most of the respondents had received acceptance of the DM disease (80.4\%), while the rest had not received it (19.6\%). The subject's perception of the illness that they suffer shows that their appreciation of the faith (Islam) is not yet complete. The impact of this phenomenon is seen that less than half of the subjects (43.5\%) think that their illness is a warning and a blessing. The majority of subjects thought that illness was believed to be just fate, an ordinary event even as a form of God's injustice. Subjects who had an optimistic attitude towards Allah regarding their illness recovery were only $45.7 \%$. The majority of subjects were doubtful, silent and pessimistic. Only $60.9 \%$ of the moods related to diabetes mellitus suffered were already fielded, while the rest were sad, angry and rejected.

The admission condition is an important thing to pay attention to, because it involves a basic psychological condition and becomes a foothold in managing long-running type 2 DM patients. From the research of Krause \& Hayward it is proven that economic difficulties that affect low health, increased depression, and low life satisfaction can be overcome with high trust in God. ${ }^{19}$ Research conducted by Jamil proved that being Ridho with destiny reduces stress on post-traumatic victims. ${ }^{20}$ Ridho is in line with the concept of acceptance and commitment therapy in overcoming distress. The RCT study conducted by Gregg et al. proved the effectiveness of the intervention "acceptance" against DM in increasing DM selfmanagement and reducing $\mathrm{HbA}_{1 \mathrm{c}}{ }^{22}$

Thirty three people $(71.7 \%)$ performed obedience in carrying out the prayers, while the rest had no awareness of the importance of worship. Furthermore, in the sick condition, only half of the subjects continued to pray, while the other half prayed occasionally and some made sickness an excuse not to perform worship. With regard to the belief that the main determinant of healing, those who answered prayer were accompanied by $63 \%$ effort, while the rest stated that the main factors were doctors, medicine and family motivation. Regarding the meaning of God's presence in a sick condition, the majority (71.7\%) were of the opinion that God was protective and full of compassion, while the rest stated that God's injustice or God was binding and controlling.

Basically, this form of obedience has great benefits for the perpetrator because it will have an impact on dependability and calmness. Worship regulates how humans can relate to God. ${ }^{23-25}$ Prayer (as the peak of worship) has an important impact in coping distress. ${ }^{2}$ The holistic approach through prayer significantly improves diabetes self-care efforts. ${ }^{27}$

Based on the category of psychospiritual status, it was found that the majority of subjects (65.2\%) had an optimal state, namely nirvana (full of meaning), while the rest (34.8\%) had a psychospiritual status that needed attention and support. The condition of the guide (guidance) as much as $17.4 \%$ were patients who were not psychologically problematic but needed spiritual guidance regarding obedience. Sorrow conditions (miserable) as much as $13 \%$, patients need psychological and spiritual support. The condition of revive (awakening) as much as $4.3 \%$ needed psychological support and spiritual strengthening. ${ }^{11}$ In this study, there was no difference in psychospiritual status between age groups and gender. This finding is in line with the statement of Taylor et al., where spirituality is not influenced by gender or age group. ${ }^{28}$ Although this is different from research conducted by Rita Hadi which found that female have a higher level of spirituality. ${ }^{29}$ It is also different from the results of research from Wika Hanida which found that male have a higher level of spirituality. ${ }^{30}$ This study was found that there was no difference in score or level of distress for gender or age group. This result is different from the research of Saad et al., which states that more female experience distress than male. ${ }^{31}$

DM type 2 patients experienced moderate depression were $28.3 \%$ while severe depression was $6.4 \%$. This is in line with the research of $\mathrm{Na}$ et al., which states that $40 \%$ of DM sufferers experience distress. ${ }^{32}$ Even Saad et al., got even more, where $73.3 \%$ occurred in female and $61.4 \%$ in male. ${ }^{31}$ In detail the research conducted by Derek et al., found that distress in type 2 diabetes mellitus patients, severe stress as many as 38 respondents $(50.7 \%)$ moderate stress as much as $36.0 \%$ and mild stress as much as $13.3 \% .33$

There is a correlation between spirituality and distress. The correlation that occurs is a negative correlation, meaning that the higher the score or level of spirituality, the lower the score or level of distress. This finding is in line with Achour et al., that religiosity is the best way for believers to overcome life's problems. ${ }^{34}$ The approach of religiosity through worship (e.g prayer) and other religious practices becomes a coping strategy that focuses on managing emotions. The results of this study strengthen the foundation of holistic patient management, especially through a spirituality approach. 


\section{mutiara medika}

CONCLUSION

There is a negative correlation between spirituality and DM distress. The higher the spirituality of the DM patient, the lower the distress and vice versa.

\section{ACKNOWLEDGEMENT}

We thanks to LP3M Universitas Muhammadiyah Yogyakarta, Faculty of Medicine and Healt Science Universitas Muhammadiyah Yogyakarta as funder dan PKU Muhamamdiyah Gamping Hospital for research area and data provider.

\section{CONFLICT OF INTEREST}

None declared

\section{REFERENCES}

1. Kementrian Kesehatan RI. Hasil Utama Riskesdas 2018. Badan Penelitian dan Pengembangan Kesehatan. 2018.

2. Virtanen M, Ferrie JE, Tabak AG, Akbaraly TN, Vahtera J, Singh-Manoux A, et al. Psychological Distress and Incidence of Type 2 Diabetes in High-Risk and Low-Risk Populations: The Whitehall II Cohort Study. Diabetes Care. 2014 Aug; 37(8): 2091-7. https://doi.org/10.2337/dc13-2725

3. Soudagar S, Rambod M. Prevalence of Stress, Anxiety and Depression and Their Associations with Spiritual Well-being in Patients with Diabetes. Sadra Med Sci J. 2018; 6(1): 1-10.

4. Tsenkova VK, Albert MA, Georgiades A, Ryff CD. Trait Anxiety and Glucose Metabolism in People without Diabetes: Vulnerabilities among Black Women. Diabet Med J Br Diabet Assoc. 2012 Jun; 29(6): 803-6. https://doi.org/10.1111/j.1464-5491.2011.3534.x

5. Semiardji G. Stres Emosional pada Penyandang Diabetes, in Soegondo S., Soewondo P., Subekti I., ed., Penatalaksanaan Diabetes Melitus Terpadu. 2013. 337-346.

6. Popoola M. Living with Diabetes: The Holistic Experiences of Nigerians and African American. Holist Nurs Pr. 2005; 19(1): 10-6. https://doi.org/10.1097/00004650-200501000-00006

7. Koenig HG. Religion, Spirituality, and Health: The Research and Clinical Implications. ISRN Psychiatry. 2012;2012:1-33. https://doi.org/10.5402/2012/278730

8. Oakley LD, Aekwarangkoon S, Ward EC. Successful Holistic Management of Type 2 Diabetes with Depression: a Very Personal Story. Holist Nurs Pract. 2011; 25(2): 88-96. https://doi.org/10.1097/HNP.0b013e31820de840

9. Casarez RLP, Engebretson JC, Ostwald SK. Spiritual Practices in Self-management of Diabetes in African Americans. Holist Nurs Pract. 2010 Jul; 24(4): 227-37. https://doi.org/10.1097/HNP.0b013e3181e903c6

10. Chen Z, Ghorbani N, Watson PJ, Aghababaei N. Muslim Experiential Religiousness and Muslim Attitudes toward Religion: Dissociation of Experiential and Attitudinal Aspects of Religiosity in Iran. Studia Religiologica 46 (1) 2013, s. 35-44 doi: https://doi.org/10.4467/20844077SR.13.003.1224

11. Ahmad J. Holistic Health Care (Psychospiritual Health Care). Buku Pendamping Panduan Dakwah Rumah Sakit Muhammadiyah 'Aisyiyah. Majelis Tabligh dan Majelis PKU Pimpinan Pusat Muhammadiyah. 2015.

12. Darvyri P, Christodoulakis S, Galanakis M, Avgoustidis AG, Thanopoulou A, Chrousos GP. O n the Role of Spirituality and Religiosity in Type 2 Diabetes Mellitus Management-A Systematic Review. Psychology. 2018 Apr 8; 9(4): 728-44. https://doi.org/10.4236/psych.2018.94046

13. Putri ASN. Gambaran Kebutuhan Spiritual pada Pasien Diabetes Melitus [Undegraduate Thesis]. Fakultas Ilmu Keperawatan, Universitas Islam Sultan Agung Semarang. 2017.

14. Putri MR. Hubungan Religiusitas dengan Diabetes Mellitus Tipe 2 di Wilayah Kerja Puskesmas Patrang Kabupaten Jember. Universitas Jember. 2017.

15. Imelda S. Faktor-Faktor yang Mempengaruhi Terjadinya Diabetes Melitus di Puskesmas Harapan Raya Tahun 2018. Sci J. 2019 May 22; 8(1): 28-39. https://doi.org/10.35141/scj.v8i1.406

16. Irawan D. Prevalensi dan Faktor Resiko Kejadian Diabetes Mellitus Tipe 2 di Daerah Urban Indonesia (Analisa Data Sekunder Riskesdas 2007) (Thesis). Universitas Indonesia. 2010.

17. Hartini S. Diabetes Siapa Takut, Panduan Lengkap untuk Diabetes, Keluarganya dan Profesional Medis. Qanita: Jakarta; 2009. 90-93.

18. Jelantik IGMG, Haryati E. Hubungan Faktor Risiko Umur, Jenis Kelamin, Kegemukan dan Hipertensi dengan Kejadian Diabetes Melitus Tipe 2 di Wilayah Kerja Puskesmas Mataram. 2013. 
19. Krause N, Hayward RD. Assessing Whether Trust in God Offsets the Effects of Financial Strain on Health and Well-Being. Int J Psychol Relig. 2015 Oct 2; 25(4): 307-22. https://doi.org/10.1080/10508619.2014.952588

20. Jamil A. Pengaruh Ridha akan Takdir dan Tipe Kepribadian terhadap Stres Pascatrauma Bencana Gempa Yogyakarta tahun 2006. Program Studi Timur Tengah dan Islam, Kekhususan Kajian Islam dan Psikologi, Universitas Indonesia. 2008.

21. Arch JJ, Craske MG. Acceptance and Commitment Therapy and Cognitive Behavioral Therapy for Anxiety Disorders: Different Treatments, Similar Mechanisms?: ACT and CBT for Anxiety Disorders • Arch \& Craske. Clin Psychol Sci Pract. 2008 Oct 23; 15(4): 263-79. https://doi.org/10.1111/j.1468-2850.2008.00137.x

22. Gregg JA, Callaghan GM, Hayes SC, Glenn-Lawson JL. Improving Diabetes Self-management through Acceptance, Mindfulness, and Values: A Randomized Controlled trial. J Consult Clin Psychol. 2007; 75(2): 336 43. https://doi.org/10.1037/0022-006X.75.2.336

23. Ilyas Y. Ihsan dan Akhlak Mulia [Internet]. 2019. Available from: www.suaramuhammadiyah.id/2019/07/09/ihsan-dan-akhlak-mulia/

24. Marzuki. Kerangka Dasar Ajaran Islam [Internet]. PKN dan FIS UNY; 2014 [cited 2019 Nov 16]. Available from: https://docplayer.info/36429026-Dr-marzuki-m-ag-dosen-pkn-dan-hukum-fis-uny-bab-v-kerangka-dasar-ajaranislam.html

25. Masroom MN, Muhamad SN, Panatik SA. The Influence of Iman, Islam and Ihsan towards the Self Wellbeing. J Hadhari. 2017;9(1):63-74.

26. Levine M. Prayer as Coping: A Psychological Analysis. J Health Care Chaplain. 2008 Aug 29;15(2):80-98.

27. Deatcher J, APRN, BC, CDE. Spiritual Self-Care and the Use of Prayer - How to Manage Your Diabetes [Internet]. Diabetes Self-Management. 2015 [cited 2021 Jul 1]. Available from: https://www.diabetesselfmanagement.com/managing-diabetes/emotional-health/spiritual-self-care-and-theuse-of-prayer/

28. Taylor C, Lilis C, LeMone P, Lynn P. Fundamentals of Nursing: The Art and Science of Nursing Care. Philadelphia: Lipincot; 2010.

29. Hadi RW. Perbedaan Pengalaman Spiritual Sehari-Hari pada Lansia di panti Wreda dan di Masyarakat. $J$ Keperawatan Komunitas. 2014 Nov; 2(2): 64-9.

30. Hanida W, Mudjaddid E, Nasution HH, Shatri H. Korelasi Aspek Spiritual dengan Kadar Interleukin-6 Serum pada Pasien Hemodialisis Kronik. J Penyakit Dalam Indones. 2017 Jan 16; 3(1): 3. http://dx.doi.org/10.7454/jpdi.v3i1.2

31. Saad NES. The Effectiveness of Foot Care Education on Patients with Type 2 Diabetes at Family Medicine Outpatient Clinics, Cairo University Hospitals. Egypt J Community Med. 2014 Apr; 32(2): 73-85.

32. Hamed MS, Ibrahim NA, Ali HM, and Kheir CG. Study of the Effect of Glycemic Control on the DiabetesRelated Distress in a Sample of Egyptian Patients with Diabetes Mellitus. Diabet Updates: 2019 (5) 1-4. https://doi.org/10.15761/DU.1000134

33. Derek MI, Rottie JV, Kallo V. Hubungan Tingkat Stres dengan Kadar Gula Darah pada Pasien Diabetes Melitus Tipe II di Rumah Sakit Pancaran Kasih Gmim Manado. E-J Keperawatan E-Kp. 2017; 5(1): 6.

34. Achour M, Grine F, Mohd Nor MR, MohdYusoff MYZ. Measuring Religiosity and Its Effects on Personal Well-Being: A Case Study of Muslim Female Academicians in Malaysia. J Relig Health. 2015 Jun 1; 54(3): 98497. https://doi.org/10.1007/s10943-014-9852-0 